\title{
OSTEOID OSTEOMA OF THE CORACOID PROCESS: CASE REPORT WITH LITERATURE REVIEW
}

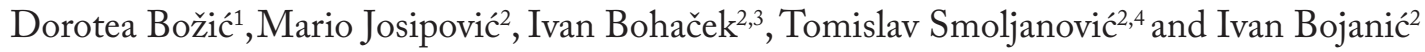 \\ ${ }^{1}$ Department of Gastroenterology, Split University Hospital Center, Split; ${ }^{2}$ Department of Orthopedic Surgery, \\ Zagreb University Hospital Center; ${ }^{3}$ Department of Anatomy and Clinical Anatomy, School of Medicine, \\ University of Zagreb, Zagreb, Croatia; ${ }^{4}$ The Elective Orthopaedic Centre, Epsom, Surrey, United Kingdom
}

\begin{abstract}
SUMMARY - Osteoid osteoma $(\mathrm{OO})$ is the most common benign osteogenic bone tumor that predominantly affects young adults. OO is commonly localized in long bones, and therefore, it is rarely considered in differential diagnosis of chronic shoulder pain. We report a case of a 22-year-old male athlete, without history of previous trauma, who presented to our Department with chronic shoulder pain, which escalated during the night and responded to nonsteroidal anti-inflammatory drug treatment. Considering these typical symptoms, diagnostic pathway was immediately directed towards $\mathrm{OO}$, with magnetic resonance and computed tomography confirming the diagnosis of $\mathrm{OO}$ of the coracoid process $(\mathrm{CP})$. Since neurovascular structures are in the proximity of $\mathrm{CP}$, and this very delicate area does not support radiofrequency ablation, we decided to perform an open procedure with drilling of the lesion and excochleation. The pain withdrew immediately after the procedure, and on six-month follow up the patient remained pain free. In the treatment of $\mathrm{OO}$ of the $\mathrm{CP}$, we recommend open surgical procedure with tumor ablation by drilling instead of $\mathrm{CP}$ resection, presenting a safe, simple and low-cost method that simultaneously completely destroys the lesion and preserves the anatomical and functional role of $\mathrm{CP}$.
\end{abstract}

Key words: Osteoma, osteoid; Scapula - pathology; Shoulder joint - pathology; Pain - therapy; Case reports

\section{Introduction}

Osteoid osteoma (OO) is the most common benign osteogenic bone tumor (75\%-85\% of all benign osteogenic bone tumors), and accounts for $4 \%-5.5 \%$ of all primary bone tumors ${ }^{1-3}$. It typically occurs in young adults, with a marked male predominance $(2-4: 1)^{1}$. Histologically, $\mathrm{OO}$ is composed of two well distinctive zones: central nidus and the surrounding zone of reactive bone sclerosis ${ }^{4}$. Prostaglandins (PG), particularly PGE2 and PGI2, released by osteoblastic tumor cells and nerve fibers found in reactive zone and in the nidus, are assumed to be a mediator responsible for se-

Correspondence to: Ivan Bohaček, $M D, P h D$, Department of Orthopedic Surgery, Zagreb University Hospital Center, Šalata 6-7, HR-10000 Zagreb, Croatia

E-mail: ivan.bohacek@gmail.com

Received December 7, 2015, accepted June 16, 2016 vere nocturnal pain, which responds well to the nonsteroidal anti-inflammatory drug (NSAID) treatment ${ }^{5,6}$.

Although this type of tumor may appear throughout the skeleton, significant predilection has been described for long bones of lower extremities, affecting femur and tibia with a prevalence of approximately $50 \%{ }^{1,7,8}$. Vertebrae are affected in approximately $10 \%$ of all cases, while the humerus, acetabulum, talus, calcaneus, metacarpus and scapula, together with coracoid process $(\mathrm{CP})$ represent atypical localizations ${ }^{7,9,10}$. $\mathrm{OO}$ of the scapula, and particularly of the $\mathrm{CP}$, is a rarely seen condition, which is the reason it is often not included in the differential diagnosis of shoulder pain in younger individuals.

A great number of methods have been described in the treatment of $\mathrm{OO}$ including a wide spectrum ranging from seldom-used conservative approach with 
NSAIDs over minimally invasive percutaneous treatments (mechanical, chemical or thermal ablation) to open surgical methods (en bloc resections and curettage techniques ${ }^{9-21}$. Therapeutic approach merely depends on numerous factors, among which anatomical localization is one of the most important factors in decision-making. Therefore, optimal therapeutic approach should be considered and selected for each patient individually.

\section{Case Report}

A 22-year-old male amateur soccer goalkeeper without history of previous trauma was referred to our Department with one-year history of left shoulder pain. The pain sensation was present constantly in the anterior part of the shoulder, spreading to the left upper arm. Pain intensity significantly escalated during the night and ceased immediately upon NSAID treatment. During clinical examination, the patient reported pain sensation in the projection of the left CP. Shoulder range of motion was neither restricted nor painful and muscle strength was well preserved. Clinical orthopedic examination of the shoulder did not reveal any specific pathology. There were no signs of fracture or other pathology present on plain anteroposterior and axillary radiographic projections (Fig. 1A). Left shoulder magnetic resonance imaging (MRI) detected a focal cystic-like lesion of the CP, which was slightly more voluminous. After application of paramagnetic contrast, the lesion displayed intensive inhomogeneous imbibition associated with perifocal soft-tissue imbibition (Fig. 1B). According to this radiological finding, $\mathrm{OO}$ of the left $\mathrm{CP}$ was sus- pected and computerized tomography (CT) was indicated. CT scan revealed a well-separated $6 \mathrm{~mm}$ wide radiolucent zone, with signs of partial sclerosis (Fig. 1C). Altogether, these findings strongly suggested the presence of $\mathrm{OO}$ in the area of the left $\mathrm{CP}$, and surgical treatment was indicated.

After thorough preoperative planning, the patient underwent open surgery in the beach chair position under regional anesthesia (ultrasound-guided interscalene brachial plexus block). A $3 \mathrm{~cm}$ long skin incision was made over the $\mathrm{CP}$, directed as a cranial extension of standard deltoidopectoral approach. Cephalic vein was exposed and retracted laterally. The tip of the $\mathrm{CP}$ and the conjoined tendons (the short head of the biceps brachii and the coracobrachialis) were identified, and after splitting the tendons in line with the fibers, the $\mathrm{CP}$ was fully exposed. According to the preoperative plan, tumor ablation by drilling together with excochleation was performed, until healthy bone was exposed on the margins. Tumor tissue was sent for histopathologic analysis. The postoperative clinical course was uneventful and the patient reported immediate pain relief after the procedure, and physical therapy was started on the first postoperative day. Later on, histopathologic analysis confirmed OO tissue. On sixmonth follow up, the patient remained pain free and did not complain of any additional symptoms.

Functional assessment of the affected shoulder was performed using the Constant Shoulder Score (CSS) and Oxford Shoulder Score (OSS) $22-25$. Preoperative CSS difference between the healthy and affected shoulder was 15 points (85 points on the left and 100 points on the right), while postoperatively there was no difference between the two sides, i.e. the score was
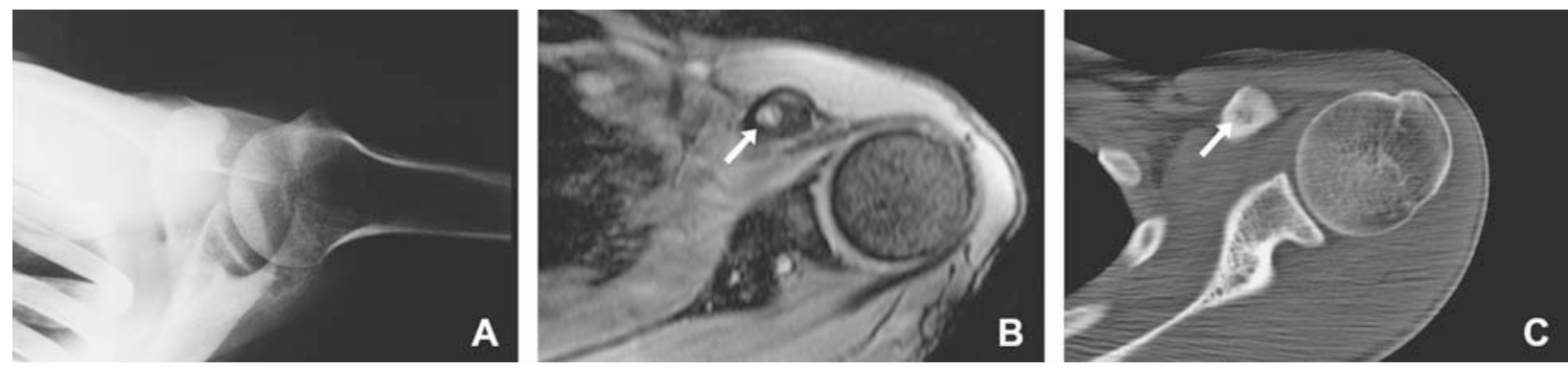

Fig. 1. (A) Plain axillary radiographic projections of the left shoulder do not reveal any signs of fracture or other underlying pathology; $(B)$ magnetic resonance imaging detected focal cystic-like lesion of the coracoid process; (C) computerized tomography revealed well-separated $6 \mathrm{~mm}$ wide radiolucent zone, with signs of partial sclerosis; $(B, C)$ white arrow indicates osteoid osteoma localized in the coracoid process. 
100 points bilaterally. Preoperative OSS was 24 on the left side, while postoperative score was maximum of 48 points, indicating that the patient was without any symptoms. Both CSS and OSS remained with maximum values on six-month follow up.

\section{Discussion and Literature Review}

Osteoid osteoma usually presents with nonspecific pain sensation, which increases during the night and responds well to NSAIDs ${ }^{6,11}$. In cases when $\mathrm{OO}$ is situated in the scapula, pain intensity and distribution may differ and therefore different shoulder pathologies are suspected, while this benign osteogenic tumor is rarely taken into account ${ }^{12,26}$. Moreover, OO localized in the $\mathrm{CP}$ usually presents with anterior shoulder pain and pathological entities such as shoulder instability, impingement syndrome or the rotator cuff tear are usually suspected ${ }^{13}$. In addition, $\mathrm{OO}$ of the $\mathrm{CP}$ may cause stiffness of the antero-superior capsule, leading to painful movement restriction or even neurological symptoms due to the affected infraclavicular brachial plexus as the result of soft tissue edema ${ }^{14,27}$. OO may also be conjoined with bone deformity, muscle atrophy or swelling of the surrounding tissues. These symptoms may resemble other clinical conditions such as osteomyelitis, Brodie abscess, stress fracture, and various bone tumors including osteoblastoma or Ewing tumor ${ }^{28}$.

Most frequently, $\mathrm{OO}$ presents with the typical radiographic sign of a small (up to $2 \mathrm{~cm}$ ) radiolucent oval nidus with the rim of the surrounding sclerotic bone $^{29}$. It is generally considered that bone tumors of the CP might be difficult to detect on plain radiographs ${ }^{26}$. However, if plain radiographs reveal reactive bone formation and osteosclerosis, CT is further indicated since it provides high sensitivity and precision, which are the key features for future treatment. In cases when the underlying tumor cannot be detected on plain radiographs, MRI is usually performed since it provides excellent visualization of both the tumor and the accompanying bone marrow edema ${ }^{14,30}$.

A great number of methods have been used in the treatment of $\mathrm{OO}$ including a wide spectrum of methods ranging from seldom used conservative approach with NSAIDs over minimally invasive percutaneous treatments which are currently considered the treatment of choice to open surgical methods.
Numerous percutaneous methods have been developed in order to precisely ablate $\mathrm{OO}$, while preserving the surrounding structures and minimizing the need for postoperative immobilization. They include CT or MRI guided percutaneous techniques, divided into three categories depending on the type of ablation: (i) mechanical ablation, which includes CT guided percutaneous drilling, with a success rate of 94\%; (ii) chemical ablation with the use of ethanol and acetic acid injections; and (iii) thermal ablation methods, which are the most widespread group of percutaneous techniques and include radiofrequency ablation (RFA), microwave ablation, cryoablation and MRI guided high intensity focal ultrasound (MRgFUS) $)^{15,16}$. RFA is currently considered as the treatment of choice ${ }^{16}$. It is both safe and efficient therapy, with a high average initial success rate of $92 \%$, low recurrence $(0-35 \%)$ and complication rates $(3 \%)^{17}$. The most common complications are thermal damage to sensitive neurovascular structures localized in the probe vicinity and skin burns, and therefore, this method was not a suitable treatment option for our patient ${ }^{16}$. In addition, we have to emphasize that percutaneous techniques often require sophisticated expensive devices, which are not available to some orthopedic centers dealing with this pathology.

Open surgical procedures include en bloc resections and curettage techniques with a success rate of $88 \%$ $100 \%{ }^{18}$. They provide immediate relief of symptoms, have a low-cost advantage, and a low relapse rate with the possibility of histopathologic verification ${ }^{9,15}$.

Coracoid process is a small hooked structure located on the scapular neck that arises anteriorly and serves as attachment for the coracoacromial, coracoclavicular and coracohumeral ligament, as well as for tendons of the coracobrachial, small pectoral and short head of the biceps brachii muscle. Since neurovascular structures pass medially to the $\mathrm{CP}$, and musculocutaneous nerve penetrates the coracobrachial muscle right under the coracoid, this is a very delicate area that does not support RFA. Therefore, we decided to perform open surgical procedure in order to protect the important anatomical structures and preserve the functional role of the CP.

According to available literature, in 1994, Kaempffe was the first to successfully perform curettage of the $\mathrm{OO}$ nidus located on the $\mathrm{CP}$ using the posterior approach $^{12}$. Later on, several other open surgical 
techniques have also been described in the literature, and in most of the cases, anterior approach was used and coracoid osteotomy was performed, followed by $\mathrm{OO}$ excision and reattachment of the $\mathrm{CP}$ using a screw $^{13,19-21}$. Although all of these reports showed excellent results after follow up period of 2-30 months, we have to be aware that osteosynthetic material remains present after the methods where $\mathrm{CP}$ reattachment using a screw was performed ${ }^{13,19-21}$. In such cases, an additional surgery may be required to remove any metal components that would interfere with CT or MRI. In addition, we have to be aware that non-union after $\mathrm{CP}$ reattachment also presents a possible complication that has not been reported in the literature so far, most probably due to the small number of published case reports. With the use of our approach, both of these complications would be excluded since $\mathrm{CP}$ remains completely intact. Accordingly, we believe that rehabilitation protocol following our surgical technique is faster and more suitable for younger population that usually practice sports activities. However, at the moment, we can only speculate about the advantages and disadvantages of different techniques, and we believe that a larger case series would be necessary to compare different approaches and to recognize the possible complications that cannot be predicted at this time.

In conclusion, for the treatment of $\mathrm{OO}$ of the $\mathrm{CP}$, we recommend open surgical procedure with tumor ablation by drilling instead of $\mathrm{CP}$ resection, presenting a safe, simple and low-cost method that simultaneously completely destroys the lesion and preserves the anatomical and functional role of the $\mathrm{CP}$.

\section{References}

1. Greenspan A, Jundt G, Remagen W. Differential Diagnosis in Orthopaedic Oncology. $2^{\text {nd }}$ edition. Philadelphia: Lippincott Williams \& Wilkins; 2007; p. 59-60.

2. Bergovec M, Kubat O, Smerdelj M, Seiwerth S, Bonevski A, Orlic D. Epidemiology of musculoskeletal tumors in a national referral orthopedic department. A study of 3482 cases. Cancer Epidemiol. 2015;39:298-302, http://dx.doi.org/10.1016/j. canep.2015.01.015

3. Niu X, Xu H, Inwards CY, Li Y, Ding Y, Letson GD, Bui MM. Primary bone tumors: epidemiologic comparison of 9200 patients treated at Beijing Ji Shui Tan Hospital, Beijing, China, with 10165 patients at Mayo Clinic, Rochester, Minnesota. Arch Pathol Lab Med. 2015;139:1149-55, http://dx.doi. org/10.5858/arpa.2014-0432-OA
4. Jaffe HL. Osteoid osteoma: a benign osteoblastic tumor composed of osteoid and atypical bone. Arch Surg. 1935;31:709-28.

5. Hasegawa T, Hirose T, Sakamoto R, Seki K, Ikata T, Hizawa K. Mechanism of pain in osteoid osteomas: an immunohistochemical study. Histopathology. 1993;22:487-91, https://dx. doi.org/10.1111/j.1365-2559.1993.tb00163.x

6. Mungo DV, Zhang X, O'Keefe RJ, Rosier RN, Puzas JE, Schwarz EM. COX-1 and COX-2 expression in osteoid osteomas.J Orthop Res. 2002;20:159-62, http://dx.doi.org/10.1016/ S0736-0266(01)00065-1

7. Gangi A, Alizadeh H, Wong L, Buy X, Dietemann JL, Roy C. Osteoid osteoma: percutaneous laser ablation and follow up in 114 patients. Radiology. 2007;242:293-301, http://dx.doi. org/10.1148/radiol.2421041404

8. Kransdorf MJ, Murphey MD. Osseous tumors. In: Davies AM, Sundaram M, James SL, editors. Imaging of Bone Tumors and Tumor-Like Llesions: Techniques and Applications. Berlin: Springer; 2009; p. 251-304.

9. Pratali R, Zuiani G, Inada M, Hanasilo C, Reganin L, Etchebehere E, Etchebehere M. Open resection of osteoid osteoma guided by a gamma-probe. Int Orthop. 2009;33:219-23, http:// dx.doi.org/10.1007/s00264-008-0552-9

10. Akhlaghpoor S, Aziz Ahari A, Arjmand Shabestari A, Alinaghizadeh MR. Radiofrequency ablation of osteoid osteoma in atypical locations: a case series. Clin Orthop Relat Res. 2010; 468:1963-70, http://dx.doi.org/10.1007/s11999-010-1265-0

11. Yokouchi M, Nagano S, Shimada H, Nakamura S, Setoguchi T, Kawamura I, Ishidou Y, Komiya S. Early complete remission of osteoid osteoma with conservative medical management. Pediatr Rep. 2014;6:5311, http://dx.doi.org/10.4081/pr.2014.5311

12. Kaempffe FA. Osteoid osteoma of the coracoid process. Excision by posterior approach. A case report. Clin Orthop Relat Res. 1994;301:260-2.

13. Akpinar S, Demirors H, Hersekli MA, Yildirim T, Barutcu O, Tandogan RN. Osteoid osteoma in the base of the coracoid process of the scapula. Excision by anterior approach: a case report. Bull Hosp Jt Dis. 2001;60:47-9.

14. Glanzmann MC, Imhoff AB, Schwyzer HK. Osteoid osteoma of the shoulder and elbow: from diagnosis to minimally invasive removal. Int Orthop. 2013;37:2403-8, http://dx.doi. org/10.1007/s00264-013-2060-9

15. Engel EE, Gava NF, Nogueira-Barbosa MH, Botter FA. CTguided percutaneous drilling is a safe and reliable method of treating osteoid osteomas. Springerplus. 2013;2:34, http://dx. doi.org/10.1186/2193-1801-2-34

16. Filippiadis DK, Tutton S, Mazioti A, Kelekis A. Percutaneous image-guided ablation of bone and soft tissue tumours: a review of available techniques and protective measures. Insights Imaging. 2014;5:339-46, http://dx.doi.org/10.1007/s13244014-0332-6

17. Gebauer B, Collettini F, Bruger C, Schaser KD, Melcher I, Tunn PU, Streitparth F. Radiofrequency ablation of osteoid osteomas: analgesia and patient satisfaction in long-term follow- 
up. Rofo. 2013;184:959-66, http://dx.doi.org/10.1055/s-00331350347

18. Cantwell CP, Obyrne J, Eustace S. Current trends in treatment of osteoid osteoma with an emphasis on radiofrequency ablation. Eur Radiol. 2004;14:607-17, http://dx.doi.org/10.1007/ s00330-003-2171-6

19. Gracia IA, Itarte JI, Majo JB, Salo GB, Proubasta IR. Osteoid osteoma of the coracoid process. J South Orthop Assoc. 2001; $10: 49-52$.

20. Gharahdaghi M, Rahimi Shorin H, Parsa A, Assadian M. En bloc resection of coracoid base osteoid osteoma in a child: an extremely rare case. Iran Red Crescent Med J. 2013;15:e9534, http://dx.doi.org/10.5812/ircmj. 9534

21. Pourfeizi HH, Sales JG, Elmi A, Tabrizi A. Osteoid osteoma of a scapula: a case report in a 34 year old woman. Med J Islam Repub Iran. 2012;26:143-6.

22. Constant CR, Murley AH. A clinical method of functional assessment of the shoulder. Clin Orthop Relat Res. 1987;214: 160-4.

23. Fabre T, Piton C, Leclouerec G, Gervais-Delion F, Durandeau A. Entrapment of the suprascapular nerve. J Bone Joint Surg Br. 1999;81:414-9.
24. Dawson J, Fitzpatrick R, Carr A. Questionnaire on the perceptions of patients about shoulder surgery. J Bone Joint Surg Br. 1996;78:593-600.

25. Dawson J, Rogers K, Fitzpatrick R, Carr A. The Oxford Shoulder Score revisited. Arch Orthop Trauma Surg. 2009;129:11923, http://dx.doi.org/10.1007/s00402-007-0549-7

26. Ogose A, Sim FH, O'Connor MI, Unni KK. Bone tumors of the coracoid process of the scapula. Clin Orthop Relat Res. 1999;358:205-14.

27. Angius D, Shaughnessy WJ, Amrami KK, Matsumoto JM, Spinner RJ. Infraclavicular brachial plexopathy secondary to coracoid osteoid osteoma. J Surg Orthop Adv. 2007;16:199203.

28. Rajeev A, Ali M, Ralte A, Chakaravathy J. Osteoid osteoma as an unusual cause of wrist pain - a case report and review of literature. Int J Surg Case Rep. 2014;5:896-8, http://dx.doi. org/10.1016/j.ijscr.2014.10.067

29. Bloem JL, Kroon HM. Osseous lesions. Radiol Clin North Am. 1993;31:261-78.

30. Zoboski RJ. Occult osteoid osteoma presenting as shoulder pain: a case report. J Chiropr Med. 2012;3:207-14, http://dx. doi.org/10.1016/j.jcm.2012.06.002

Sažetak

\section{OSTEOID OSTEOM KORAKOIDNOG NASTAVKA: PRIKAZ SLUČAJA I PREGLED LITERATURE}

\section{Božic, M. Josipović, I. Bohaček, T. Smoljanović i I. Bojanić}

Osteoid osteom (OO) je dobroćudni osteoblastični tumor kostiju koji se najčešće javlja u adolescenata i mlađih odraslih osoba. Uobičajena lokalizacija $\mathrm{OO}$ su duge kosti pa se rijetko razmatra u diferencijalnoj dijagnostici kronične boli u području ramena. Prikazujemo slučaj mladog sportaša u dobi od 22 godine koji se žalio na bolove u lijevom ramenu, i to bez prethodne ozljede. Intenzitet boli značajno se pojačavao tijekom noći, a bol se smirivala nakon primjene nesteroidnih protuupalnih lijekova. Ovi tipični simptomi odmah su usmjerili dijagnozu k OO, a magnetska rezonancija i kompjutorizirana tomografija pokazale su da je riječ o OO korakoidnog nastavka skapule. Budući da se žilnoživčani snop nalazi u blizini korakoidnog nastavka radiofrekventna ablacija nije prikladna metoda za liječenje $\mathrm{OO}$ te lokalizacije pa smo se odlučili za kirurško liječenje. Načinili smo ablaciju tumora svrdlanjem te ekskohleacijom. Od operacijskog zahvata bolesnik se više nije žalio ni na kakvu bol u području lijevog ramena. S obzirom na današnje spoznaje savjetujemo da se OO korakoidnog nastavka svakako liječi kirurškim zahvatom tijekom kojeg valja tumor uništiti svrdlanjem. Za razliku od resekcije korakoidnog nastavka, svrdlanjem se u potpunosti uništava leziju i istodobno čuva integritet korakoidnog nastavka, što je od velikog anatomskog i funkcionalnog značenja.

Ključne riječi: Osteom, osteoidni; Skapula-patologija; Rameni zglob-patologija; Bol-terapija; Prikazi slučaja 